\title{
The Effect of Value Clarification Technique (VCT) using Contextual Problem Content on Social Attitude and Social Science Learning Achievement of the Elementary School Students
}

\author{
Desak Putu Parmiti, ${ }^{1, *}$ \\ ${ }^{1}$ Educational Technology Department, Universitas Pendidikan Ganesha, Singaraja, Indonesia
}

\begin{abstract}
This study analyzed and described changes in social attitude and social science learning achievement of the students who learn through value clarification technique (VCT) with contextual problem content and the students who learn through conventional teaching. This experiment or research was conducted at SD Gugus in Buleleng Regency with the population of 503 students. The number of sample for the experiment group was 40 students, and that for the control group was 40 too. The study used social attitude questionnaires and social study learning test to collect the data, while descriptive analysis and inferential analysis were used for analyzing the data. In this study, it was found (1) there was a significant difference in social attitude between the students who learned through VCT with contextual problem content and those who learned through conventional teaching, (Fobs. $=6.370$ ), (2) there was a significant different in learning achievement between the students who learned through VCT with contextual problem content and those who learned through conventional teaching, (Fobs. $=4.040$ ), and (3) there was a significant difference between social attitude and social science learning achievement simultaneously between the students who learned through VCT with contextual problem content and those who learned through conventional teaching. It means that the effect of teaching with VCT with contextual problem content in social science teaching produce a higher social attitude and social science learning achievement than the conventional teaching. Keywords: Value Clarification Technique (VCT), contextual problem, Social attitude, and learning achievement
\end{abstract}

\section{Introduction}

Social science teaching is a strategic means in developing the students to become sociable citizens (Hasan, 2005). Thus, social science teaching will help the students to have an independent personality, physically and mentally healthy, and to become useful members of society. An independent person is someone who is able to grow holistically and harmoniously from all aspects of

* Corresponding author: dskpt_parmiti@yahoo.co.id 
humanity and is able to respect humanity of everyone. There are also people who say that social science knowledge is the field of social science that is used by the students to solve problems that he/she faces. Social science teaching has the function and role which are very strategic in the effort of developing good and reliable citizens with the goal of building the nation (Lasmawan, 2010).

As an educator, a teacher is one of determiners in the success of every educational effort. That is why when there is an education innovation, especially in curriculum and human resource improvement resulted from educational efforts always lead to teacher factor. This shows how strategic the teachers' role is in the world of education. Thus, there is a need for teachers who are able to design teaching process, so the teaching can run well, joyfully, effectively, and efficiently. The statement above is supported by Sanjaya (2010) who states that teacher is a very important component in the success of the implementation of educational process. To create a joyful learning process, a teacher is not allowed to transfer whatever is explain in the text book to the students, it is a wrong action. The current teaching process focuses on how students find themselves through direct and real experience, can be proven based on theories or facts. Social science teaching is also one of the subjects that are not only based on the theory but also on facts.

Some research findings also state the condition of social science teaching at elementary schools today, it turns out that many students find difficulty in learning in the classroom because the technique of teaching selected on used by the teacher is felt to be less appropriate (Sumantri, 1999), thus the teaching and learning process will run awkwardly and is not supported by the development of knowledge, attitude, moral, and skill students development (Hasan, 1997). The problem is also felt in the students learning achievement in social science which has not reached the maximum learning mastery level that is it only reaches $69 \%$, while the target of mastery is $75 \%$. The low quality in the process and product of social science teaching was seen from the methodic and DIADECTIC perspective is assumingly caused by some factors, both internal and external. The problems faced in the field are: (1) the teaching method used by the teacher is still conventional, largely using lecturing method, (2) the number of students is too big for one class, (3) the equipments and media for learning are still very minimal, (4) the supplementary books are still lacking, (5) advancement in science and technology has not been used optimally, (6) infrastructure and facilities are not yet representative, (7) the evaluation done by the teachers focuses more on cognitive concept mastery without considering attitude and skill, (8) the classroom atmosphere is less conducive, (9) the environment and school stick holders do not care much about the condition.

With the implementation of school based curriculum in 2006, teachers are required to be able to develop the curriculum according to the potentiality, development of the students, their needs, school environment, and the development in science and technology (BSNP, 2006). The teaching expected in school based curriculum is (1) stresses more on students centered learning, (2) competency based, (3) and the newest one is that the teacher has to I2M3. Thus, teachers have to be able to develop the model of teaching that can change the teaching and learning process: from teacher-centered to student-centered, from content based to competency based. In this context Sommers (1993) states one of the important method in moral education is value clarification method (value clarification). By using this method, the teacher does not directly present to the students about the correctness or the incorrectness of something but on the contrary the students have to be given the opportunity to states their values in their own way. Furthermore, it is suggested that (1) schools have to have rules for behavior that stress the important of politeness, virtuous, self discipline, and honesty; (2) teacher should not indoctrinize the students if they want to ask something firmly on the basis of politeness, honesty, and openness; (3) the students have to be told stories that focus on good principals and the students should be fond of READING, learning and discussing or issues.

In Values Clarification Technique (VCT) development in this context of study, the focus of problems will be directed to the VCT testing of the students' social attitude and learning achievement.

Based on the empirical and conceptual studies above, it seems that VCT is one of techniques in social science teaching that is visible to be investigated in depth and scientifically especially in relation to social science teaching at elementary school level. This discussion enables us to combine VCT teaching and contextual teaching in social science teaching. Such kind of teaching will produce new and innovative characteristic, so that teaching will be more productive, joyful and inspiring. Teaching with contextual problems is the teaching that occurs in close relation the real experience. Contextual approach is concept that combines the findings of many researches recently in cognitive science. Viewed from the students' aspect, teaching with contextual problems has the probability for 
fostering knowledge strongly in the students, developing the student cognitive ability, and full with the development of social aspects in the students.

Based on the above explanation, the teaching with contextual problem content and conventional teaching have different characteristic. The characteristic different will cost consequences in the way of the result of teaching that the students get, and this is assumed to influence social attitude and learning achievement. However to what extends thus the teaching with VCT with contextual problem content in social science teaching has an effect on the students social; skill and learning achievement, especially the student of 5th grade at SD Gugus VI in Buleleng regency. Therefore, the aim of this study was to analyze and describe (1) difference in social attitude between the students who learn through VCT with contextual problem and those who learn through conventional teaching, (2) difference in the students social learning achievement of those who learn through VCT with contextual problem content and those who learn through conventional teaching, (3) simultaneously, the difference in social attitude and social science learning achievement of the students who learn through VCT with contextual problem content and those who learn through conventional teaching.

\section{Researches Method}

The dependent variables which were used as the object in this study were social as attitude and students social achievement. The independent variables to be tested in this study were with the teaching using VCT with contextual problem content and conventional teaching model. The study used an experiment design, that is, posttest only controls group design.

The population in this study was all students of the 5th grade of SD Gugus VI, Buleleng regency with the total of 12 classes and the number of students were 503 students.

The sampling tech use in this study was classroom sampling technique. The classroom sampling tech was selected in this study because the object or the targets of the sampling in this study were classes in Gugus VI Buelelng regency, rather than individuals (students in group).

Based on the characteristic of the population, the sample in this study was drawn by random sampling technique. The selection and determining experiment and control groups was done by using random sampling technique of the equivalent class pairs selected as sample.

The data collected in this study consisted of (1) social skill, (2) learning achievement. This social attitude questionnaire was written and developed by researcher herself with the approval from some judges. In the same way the learning achievement test improvement was made and developed by researcher herself with the approval from some judges. Social learning achievement in this study focuses on cognitive domain that is to meter social science learning achievement.

The methods of analyzing the data used in this study were descriptive analysis method and inferential analysis method to test the hypothesis was MANOVA analysis. Edited by SPSS-16.0 forwindows and the hypothesis testing is done by Hotelling's Trace (Hair, et all, 1998: 334) since it involved two dependant variable (multivariate) by comparing two different groups, that is, experimental and control group. The testing criterion: if the value of Hotelling Trace yielded a significant level below 0.05 , then the null hypothesis was rejected and otherwise the null hypothesis was accepted (Santosa, 2002:219).

\section{Results And Discussion}

The description of the results in mean modus and median and the data spread can be seen in table 1.

Table 1. Recap of the result of computation of the student's social studies learning achievement score and the student social attitude.

\begin{tabular}{|l|c|c|c|c|}
\hline \multirow{2}{*}{ Statistic } & \multicolumn{2}{|c|}{ Learning Achievement } & \multicolumn{2}{c|}{ Social Attitude } \\
\cline { 2 - 5 } & VCT & Conventional & VCT & Conventional \\
\hline $\mathrm{N}$ & 40 & 40 & 40 & 40 \\
\hline Mean & 27.15 & 24.90 & 109.95 & 100.05 \\
\hline
\end{tabular}




\begin{tabular}{|l|c|c|c|c|}
\hline Median & 27 & 25.50 & 112.00 & 97.00 \\
\hline Variance & 25.669 & 24.451 & 292.356 & 323.126 \\
\hline Mood & 25 & 23 & 120 & 110 \\
\hline $\begin{array}{l}\text { Satandard } \\
\text { deviation }\end{array}$ & 5.066 & 4.945 & 17.098 & 17.976 \\
\hline Minimum score & 18 & 13 & 78 & 72 \\
\hline Maximum score & 35 & 34 & 140 & 140 \\
\hline Range & 17 & 21 & 62 & 68 \\
\hline Class number & 6 & 6 & 6 & 6 \\
\hline Class length & 3 & 4 & 11 & 12 \\
\hline
\end{tabular}

Before the hypothesis testing was conducted by using the statistical method with the one way ANAVA and MANOVA prerequisite test was conducted first. Based on the statistical test with the aid from SPSS, the variable of social attitude and learning achievement in the teaching using VCT with contextual problem content and conventional teaching were normally distributed and had homogenous variants or the data came from populations with the same variant. The result of computation showed between groups probability value for students social attitude was 0.14 lower than 0.05 . It means there was a significant difference in social attitude between the students who learn through the teaching using VCT with contextual problem content and that of student who learn through conventional teaching model. The students who learn through teaching using VCT with contextual problem content had scored in social attitude with the means of 105.95; while the group of students who learn through conventional teaching had the means of 100.05 for social attitude. This means that the students' social attitude for those who learn through the teaching using VCT with contextual problem content differs from those who learn through conventional teaching model. Furthermore, the calculation of one tailed T test yielded Tobs.-5.18 and tc.v with $\mathrm{df}=94$ at the 0.05 level of significant was 1.658. this means Tobs. $>$ tc.v, thus it can be concluded that social attitude is the groups of students who learn through teaching using VCT with contextual problem content was higher than the group of students who learn through conventional teaching model at the 0.05 level of significant.

In the testing of the second hypothesis, one way ANOVA was used. The result showed that between groups probability or social science learning achievement was 0.048 smaller than 0.05 . This means that there was significant different between the social science students who learn through the teaching using VCT technique with contextual problem content and that of the students who learn through conventional teaching model. The result of analysis also showed that the group students who learn through the teaching using VCT technique with contextual problem content had a means of 27.15; while the group of students who learn through conventional teaching had the means for 24.90 . furthermore, the result of one tailed $\mathrm{T}$ test competition showed that Tobs. $=-5.18$ and tc.v at $\mathrm{df}=94$ at the 0.05 level of significant $=1.658$, which means that tobs $>$ tc.v, thus it can be concluded that social science achievement of the students who learn through the teaching using VCT technique with contextual problem was better that that students through conventional teaching model at 0.05 level of significant.

The simultaneous difference of the students' social science learning achievement and the students' social science attitude of those who learn through teaching following VCT with contextual problem content and those using conventional teaching model was done using ANAVA.

\section{Table 2. Recap of the Result of Computation of Social Learning Achievement and Students' Social Attitude by One Way MANOVA Edited by SPSS 16.0 for-windows.}

\begin{tabular}{|l|l|l|l|l|l|l|}
\hline \multirow{2}{*}{ Effect } & Statistic & Value & F & $\begin{array}{l}\text { Hyphothesis } \\
\text { df }\end{array}$ & Error df & Sig. \\
\hline \multirow{2}{*}{ Intercept } & Pillai's Trace & 0.983 & 2224.210 & 2.000 & 77.000 & 0.000 \\
\cline { 2 - 7 } & Wilks' Lambda & 0.017 & 2224.210 & 2.000 & 77.000 & 0.000 \\
\hline
\end{tabular}




\begin{tabular}{|l|l|l|l|l|l|l|}
\hline & $\begin{array}{l}\text { Hotelling's } \\
\text { Trace }\end{array}$ & 57.772 & 2224.210 & 2.000 & 77.000 & 0.000 \\
\cline { 2 - 7 } & $\begin{array}{l}\text { Roy's Largest } \\
\text { Root }\end{array}$ & 57.772 & 2224.210 & 2.000 & 77.000 & 0.000 \\
\hline A & Pillai's Trace & 0.107 & 4.614 & 2.000 & 77.000 & 0.013 \\
\hline & Wilks' Lambda & 0.893 & 4.614 & 2.000 & 77.000 & 0.013 \\
\hline & $\begin{array}{l}\text { Hotelling's } \\
\text { Trace }\end{array}$ & 0.120 & 4.614 & 2.000 & 77.000 & 0.013 \\
\hline & $\begin{array}{l}\text { Roy's Largest } \\
\text { Root }\end{array}$ & 0.120 & 4.614 & 2.000 & 77.000 & 0.013 \\
\hline
\end{tabular}

Based on the result of analysis in table 2, the F values of Pillai's Trace, Wilks' Lambda, Hotelling's Trace, and Roy's Largest Root had the level of significant smaller than 0.05. It means the F values for Pillai's Trace, Wilks' Lambda, Hotelling's Trace, and Roy's Largest Root were significant. This means that the students' social attitude and social science learning achievement of student learning through teaching using VCT technique with contextual problem content was better than that use conventional teaching model.

\section{Discussion}

This study was supported by the research done by Winata (2010) entitled the effect of implementing VCT and achievement motivation on the civic learning achievement of the students of class V SD Gugus 1 Mendoyo and Jandut Gregorius (2011) in Education Journal sixth edition No. 4 2011 entitled Implementation of Modified of VCT Model as An Effort To Develop An Awareness of Students in Civic Lesson in SDN Sumur Welut.

The result of analysis showed that there was difference in social learning achievement and social attitude simultaneously between the students using VCT technique with contextuall problem contenta and those who learn through conventional teaching model. These student social science attitudes were affected by various factors, which include the tech of teaching use by the teacher. Since the teacher has to select teaching technique that is suitable for the certain topic in order to achieve the teaching objective that will be reached. The teacher in teaching is expected not only to develop the cognitive domain, but he or she has to develop effectiveve psychomotor domain too. This is in line of the nature of social science as the product and social science as process. Based on the result of this study, teachers need to be aware that not all topics can be taught by the same teaching technique especially in relation of the development of student social attitude and improvement of the students' social science learning achievement. The teaching by using VCT technique with contextual problem content stresses the important of the students improvement holistically to define the material to be learn and to relate it to the real life situation that motivate students to be able to apply it in real life. From that concept there are 3 things that can be observed. First, the teaching using VCT with contextual problem content stresses the important of direct experience process. The learning process in teaching using VCT with contextual problem content does not expect the students to only receive lesson but also put an emphasize on the process of seeking and finding the material by the students themselves.

Second, the teaching through VCT with contextual problem content encourages student to be able to finds the relation of material being learn and the real life situation, that means students are required to be able to catch the relation between the students learning problem at school and real life, the material will not only be meaningful functionally but it will be learn in a close relation deeply in students memory, it cannot be easily forgotten.

Thirda, the teaching through VCT with contextual problem content encourages the students to be able to apply what they learn in real life, it means the teaching through VCT with contextual problem content does not to only expect students to be able to understand the material learned but also how the material to be colored with their behavior in real life. The material in the teaching through VCT with contextual problem content is not aimed at collecting the material in the brain and are forgotten but as their asset in living in the real life. 


\section{Conclusion}

Based on the result, it can be concluded that (1) the teaching approach using VCT with contextual problem content in social science teaching produces higher social skill than conventional teaching approach, and (2) the effect of the approach with VCT with contextual problem content in social science teaching produce a better learning achievement than the result of conventional teaching model, (3) the effect of teaching through VCT with contextual problem content on social science teaching produce better social attitude and social science learning achievement compared to conventional teaching model. Based on the findings on this study, then some suggestion can be made, namely (1) the teaching through VCT with contextual problem content has a comparative advantage in improving the students social attitude and students' social learning achievement, thus it is recommended to the elementary school social science teacher to use the teaching through VCT with contextual problem content to improve students' social attitude and learning achievement. (2) To the decision makers in education, especially in social science education, it is suggested that they consider the teacher tech applied in this study as an innovation in teaching, so that the social science teaching objectives can be reached optiomally.

\section{References}

[1] BSNP. 2006. Panduan Penyusunan Kurikulum Tingkat Satuan Pendidikan Jenjang Pendidikan Dasar dan Menengah. Jakarta: Pusat Kurikulum.

[2] Hasan. 1997. Pendidikan Ilmu-ilmu Sosial (Buku I). Bandung: Jurusan Sejrah fakultas PPKn IKIP Bandung.

[3] Hasan, S.H. 2005. Pembaharuan PKn di Era Otonomi Pendidikan. Makalah, Disajikan dalam seminar sehari Fakultas PPKn IKIP Negeri Singaraja.

[4] Lasmawan, Wayan. 2010. Menelisik Pendidikan IPS Dalam Perspektif Kontekstual-Empiris. Singaraja : Mediakom Indonesia Press Bali.

[5] Sanjaya, Wina. 2010. Strategi Pembelajaran Berorientasi Standar Proses Pendidikan. Jakarta: Prenada Media Group.

[6] Santoso, Singgih. 2002. SPSS Versi 11.5 Cetakan Kedua. Jakarta: Gramedia.

[7] Sommers, Kathleen. 1997. Core Competency-Based Strategy. London: International Thomson Business Press.

[8] Sumantri, E. 1999. Desentraisasi Pendidikan dan Wacana Demokrasi dalam Konteks Pendidikan Nasional. Makalah disajikan dalam Seminar Lembaga Penelitian UPI Bandung.

[9] Winata. 2010. Strategi Belajar Mengajar. Jakarta: Universitas Terbuka. 